\title{
Synthesis, Surface Properties and Biological Activity of Long Chain Ammonium Herbicidal Ionic Liquids
}

\author{
Rafat Giszter, ${ }^{* a}$ Marta Fryder, ${ }^{a}$ Katarzyna Marcinkowska ${ }^{b}$ and Agata Sznajdrowska ${ }^{a}$ \\ ${ }^{a}$ Department of Chemical Technology, Poznan University of Technology, 60-965 Poznan, Poland \\ ${ }^{b}$ Institute of Plant Protection, National Research Institute, 60-965 Poznan, Poland
}

\begin{abstract}
Herbicidal ionic liquids exhibit many advantages compared to conventional chemical plant protection agents, which allow for a reduction of the herbicide dose per hectare and decrease of toxicity. Popular herbicides, such as 4-chloro-2-methylphenoxyacetic (MCPA) or 2,4-dichlorophenoxyacetic (2,4-D) acids, can be modified by reaction with long chain ammonium cations in order to obtain novel forms. The aim of this study was to present an alternative method for the synthesis of herbicidal ionic liquids based on a natural cation known as Ethoquad C/12 and to analyze the physicochemical properties and herbicidal activity of the obtained products. New ionic liquids comprising MCPA and 2,4-D as anions were obtained and their chemical as well as thermal stability were evaluated. Furthermore, their biological and surface activity were investigated. The obtained results confirmed that the herbicidal activity has been preserved.
\end{abstract}

Keywords: herbicidal ionic liquids, herbicidal activity, wettability

\section{Introduction}

Ionic liquids (ILs) are a class of organic salts, which are liquids below $100{ }^{\circ} \mathrm{C}$. They have attracted much attention because of their unique properties, such as high thermal stability, low volatility and non-flammability. ${ }^{1,2}$ The number of application of ILs has recently increased: they can be employed as useful solvents in diverse fields, such as organic synthesis, chemical catalysis, separation technology, and novel electrolytes for batteries.-5 Due to their structural variety, there is also a considerable number of different ILs resulting from the combination of diverse cations and anions, which allows to design them for particular applications. Nowadays, there is an extensive list of literature reports regarding successive applications of already known ILs. Additionally, new possible applications were also discovered since ILs with pharmaceuticals, ${ }^{6}$ antifeedants ${ }^{7,8}$ or fungicidal activity were recently introduced. ${ }^{8,9}$

Modern agriculture depends on effective control of pests and weeds. Chemicals in agriculture have significantly influenced the quality and quantity of food available for the growing world population. The application of herbicides is critical to increase food production, reduce the cost of

*e-mail: rafal.giszter@put.poznan.pl farming and, at the same time, reduce the labor necessary for weed control practices.

In 2011, a new group of ILs called herbicidal ionic liquids (HILs) was described..$^{10}$ This herbicidal group of ionic liquids may be applied as weed control agents in crop protection. The initial research included HILs comprising anion from a single class of herbicides: phenoxyacids. ${ }^{10}$ Phenoxyacids are a popular group of herbicides which have been commercialized since the 1940s and they are still commonly used in weed control. ${ }^{11}$ The most important commonly used compounds include 4-chloro-2-methylphenoxyacetic acid (MCPA) and 2,4-dichlorophenoxyacetic acid (2,4-D). A phenoxy herbicide is a member of a family of chemicals related to the indoleacetic acid (IAA) growth hormone. When sprayed on broadleaf plants they induce rapid, uncontrolled growth, eventually killing the weeds. ${ }^{12}$ Currently, chemical herbicides have a decisive impact on the protection of crop plants, because their application is the most effective and cheapest method.

HILs exhibit many advantages compared to chemical plant protection; agents allow for a reduction of the herbicide dose per hectare and decrease of toxicity..$^{10,13-18}$ Reduced volatility contributes to their safer use by operators and reduction of overall environmental impact of the employed herbicide. ${ }^{16}$ Solubility in water can be reduced 


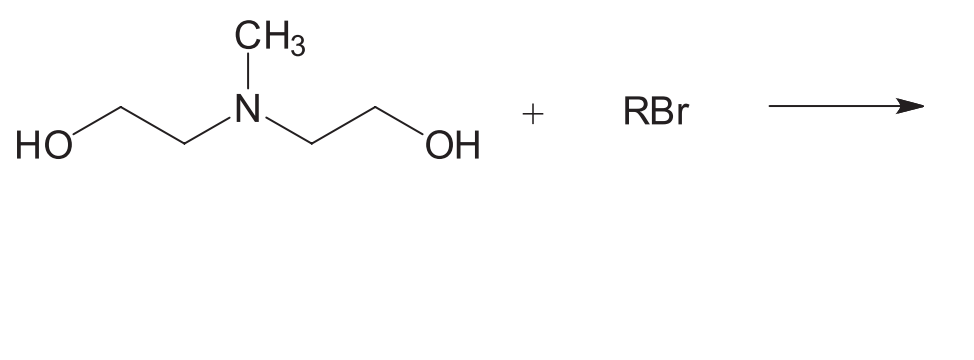

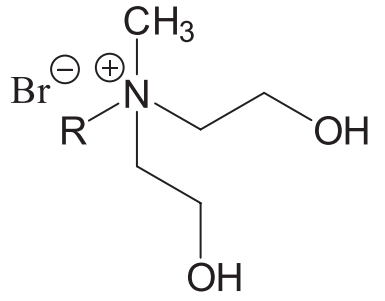

(1-3)

Scheme 1. Synthesis of quaternary ammonium bromide.

by appropriate selection of the cation, which contributes to reduced mobility in soil and groundwater. ${ }^{14}$ Moreover, HILs display multifunctional properties and may be used in order to reduce the number of additional chemical such as adjuvants or surfactants, which are required per application. The risk of adverse effects of HILs on the environment is reduced, because they will not react with the metal ions present in soil. Additionally, they offer significant advantages and are viable alternatives to other currently used forms of herbicides. ${ }^{16}$

HILs mostly exhibit herbicidal activity, however, they may display additional traits when a herbicidal anion is combined with a cation, which exhibits appropriate properties, such as plant growth inhibition ${ }^{19}$ or fungicidal activity. ${ }^{20}$ The newest research reports introduced glyphosate- ${ }^{21}$ metsulfuronmethyl- ${ }^{22}$ and bis(ammonium)-based HILs. ${ }^{23}$ The novel HILs are often based on Ethoquad C/12, a mixture of bis(2-hydroxyethyl)alkylmethylammonium cations of natural origin. These cations comprise alkyl constituents with 8 to 18 carbon atoms and are used as emulsifiers, dye components, thickeners and as antistatic agents. It is plausible that HILs based on cations with a specific carbon chain length may differ in terms of properties and herbicidal activity, therefore it is imperative to compare the effects of defined cations, which represent the constituents of Ethoquad C/12, on the performance of HILs.

The aim of this study was to evaluate the physicochemical properties as well as surface and herbicidal activity of newly synthesized HILs based on the alkylbis(2-hydroxyethyl) ammonium cation and MCPA or 2,4-D anions. This study attempts to evaluate the influence of cations with specific alkyl chain length on the herbicidal activity. The length of the alkyl chain substituent was equal to fourteen, sixteen and eighteen carbon atoms.

\section{Experimental}

\section{General}

${ }^{1} \mathrm{H}$ nuclear magnetic resonance (NMR) spectra were recorded using a Mercury Gemini 300 spectrometer operating at $400 \mathrm{MHz}$ with tetramethylsilane as the internal standard. ${ }^{13} \mathrm{C}$ NMR spectra were obtained using the same instrument at $75 \mathrm{MHz}$. CHN elemental analyses were performed at A. Mickiewicz University, Poznan (Poland).

Preparation of alkylbis(2-hydroxyethyl)ammonium bromide

In a round-bottom flask, $0.1 \mathrm{~mol}$ of the appropriate bromoalkane was dissolved in $75 \mathrm{~mL}$ of acetonitrile. Next, bis(2-hydroxyethyl)methylamine was added with a $10 \%$ excess. The synthesis was conducted at the boiling point temperature of the solvent for $24 \mathrm{~h}$ (Scheme 1).

Then, the solvent was removed by a vacuum evaporator and $100 \mathrm{~mL}$ of ethyl acetate were added. The product, which precipitated in the form of a white solid, was isolated by filtration, washed with small portions of ethyl acetate $(2 \times 15 \mathrm{~mL})$ and dried under reduced pressure at $70{ }^{\circ} \mathrm{C}$ for $24 \mathrm{~h}$ (Table 1).

Table 1. Prepared quaternary ammonium bromides

\begin{tabular}{lccccc}
\hline Run & $\mathrm{R}$ & Anion & Yield / \% & $\begin{array}{c}\text { Melting } \\
\text { point } /{ }^{\circ} \mathrm{C}\end{array}$ & Purity / \% \\
\hline 1 & $\mathrm{C}_{14} \mathrm{H}_{29}$ & $\mathrm{Br}^{-}$ & 92 & $109-110$ & 99 \\
2 & $\mathrm{C}_{16} \mathrm{H}_{33}$ & $\mathrm{Br}^{-}$ & 91 & $114-115$ & 98 \\
3 & $\mathrm{C}_{18} \mathrm{H}_{37}$ & $\mathrm{Br}^{-}$ & 90 & $115-116$ & 96 \\
\hline
\end{tabular}

\section{Preparation of ammonium acetates}

The appropriate alkylbis(2-hydroxyethyl)ammonium bromide $(0.01 \mathrm{~mol})$ was introduced into a round-bottom flask and dissolved in $50 \mathrm{~mL}$ of anhydrous methanol, followed by the addition of $0.01 \mathrm{~mol}$ of potassium hydroxide dissolved in $25 \mathrm{~mL}$ of methanol. The reaction was conducted for $30 \mathrm{~min}$ at room temperature and the precipitated inorganic by-product (potassium bromide) was removed by filtration. Then, the filtrate containing quaternary ammonium hydroxide was neutralized with stoichiometric amount of MCPA or 2,4-D (1a-3b). Then solvent was removed under reduced pressure and the crude product was obtained. Afterwards, the residue was 
<smiles>[R][N+](C)(Br)CCO</smiles>

(1-3)

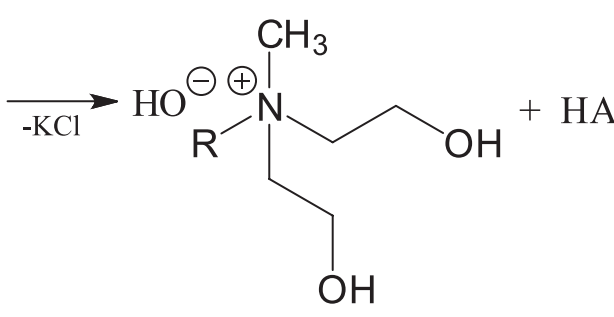

Scheme 2. General synthesis of salts with MCPA and 2,4-D anion.

dissolved in $50 \mathrm{~mL}$ of acetone and inorganic salt and other residues were filtered off. After the evaporation of acetone, the synthesized salts were dried under vacuum for $24 \mathrm{~h}$ at the temperature of $70{ }^{\circ} \mathrm{C}$ (Scheme 2). Purity was determined by a direct two-phase titration technique (International Organization for Standardization European standard (EN ISO) 2871-2-2010) (Table 2).

Table 2. Prepared salts

\begin{tabular}{cccccc}
\hline Salt & $\mathrm{R}$ & Anion & $\begin{array}{c}\text { Yield / } \\
\%\end{array}$ & $\begin{array}{c}\text { Melting } \\
\text { temperature / }{ }^{\circ} \mathrm{C}\end{array}$ & $\begin{array}{c}\text { Purity / } \\
\%\end{array}$ \\
\hline $\mathbf{1 a}$ & $\mathrm{C}_{14} \mathrm{H}_{29}$ & MCPA & 99 & $69-71$ & 99 \\
$\mathbf{2 a}$ & $\mathrm{C}_{16} \mathrm{H}_{33}$ & MCPA & 98 & $52-54$ & 97 \\
$\mathbf{3 a}$ & $\mathrm{C}_{18} \mathrm{H}_{37}$ & MCPA & 99 & $59-61$ & 98 \\
$\mathbf{1 b}$ & $\mathrm{C}_{14} \mathrm{H}_{29}$ & $2,4-\mathrm{D}$ & 96 & liquid & 97 \\
$\mathbf{2 b}$ & $\mathrm{C}_{16} \mathrm{H}_{33}$ & $2,4-\mathrm{D}$ & 97 & $49-51$ & 96 \\
$\mathbf{3 b}$ & $\mathrm{C}_{18} \mathrm{H}_{37}$ & 2,4-D & 95 & $69-71$ & 96 \\
\hline
\end{tabular}

MCPA: 4-chloro-2-methylphenoxyacetic anion; 2,4-D: 2,4-dichlorophenoxyacetic anion.

Bis(2-hydroxyethyl)methyltetradecylammonium bromide (1)

${ }^{1} \mathrm{H}$ NMR $\left(400 \mathrm{MHz}, \mathrm{CDCl}_{3}\right) \delta 0.88(\mathrm{t}, 3 \mathrm{H}, J 6.7 \mathrm{~Hz}$, $\left.\mathrm{CH}_{3}\right), 1.26\left(\mathrm{~s}, 22 \mathrm{H}, \mathrm{CH}_{2}\right), 1.76\left(\mathrm{~d}, 2 \mathrm{H}, J 5.5 \mathrm{~Hz}, \mathrm{CH}_{2}\right), 3.34$ $\left(\mathrm{m}, 3 \mathrm{H}, \mathrm{CH}_{3}\right), 3.56\left(\mathrm{~m}, 4 \mathrm{H}, \mathrm{CH}_{2}\right), 3.75\left(\mathrm{~m}, 4 \mathrm{H}, \mathrm{CH}_{2}\right), 4.10$ (s, $\left.4 \mathrm{H}, \mathrm{CH}_{2}\right), 4.80(\mathrm{~s}, 2 \mathrm{H}, \mathrm{OH}) ;{ }^{13} \mathrm{C} \mathrm{NMR}\left(100 \mathrm{MHz}, \mathrm{CDCl}_{3}\right)$ $\delta$ 14.0, 22.5, 26.3, 29.2 (4), 29.4 (4), 29.5 (3), 31.7, 50.3, 55.6, 63.6, 63.9; anal. calcd. for $\mathrm{C}_{19} \mathrm{H}_{42} \mathrm{BrNO}_{2}$ : C, 57.56; $\mathrm{H}, 10.68$; N, 3.53; found: C, 57.99; H, 10.20; N, 4.10.

Hexadecylbis(2-hydroxyethyl)methylammonium bromide (2)

${ }^{1} \mathrm{H}$ NMR $\left(400 \mathrm{MHz}, \mathrm{CDCl}_{3}\right) \delta 0.88(\mathrm{t}, 3 \mathrm{H}, J 6.7 \mathrm{~Hz}$, $\left.\mathrm{CH}_{3}\right), 1.26\left(\mathrm{~s}, 26 \mathrm{H}, \mathrm{CH}_{2}\right), 1.76\left(\mathrm{~d}, 2 \mathrm{H}, J 5.5 \mathrm{~Hz}, \mathrm{CH}_{2}\right), 3.34$ $\left(\mathrm{m}, 3 \mathrm{H}, \mathrm{CH}_{3}\right), 3.56\left(\mathrm{~m}, 4 \mathrm{H}, \mathrm{CH}_{2}\right), 3.75\left(\mathrm{~m}, 4 \mathrm{H}, \mathrm{CH}_{2}\right), 4.10$ (s, $\left.4 \mathrm{H}, \mathrm{CH}_{2}\right), 4.80(\mathrm{~s}, 2 \mathrm{H}, \mathrm{OH}) ;{ }^{13} \mathrm{C} \mathrm{NMR}\left(100 \mathrm{MHz}, \mathrm{CDCl}_{3}\right)$ $\delta$ 14.0, 22.5, 26.3, 29.2 (4), 29.4 (4), 29.5 (5), 31.7, 50.3, 55.6, 63.6, 63.9; anal. calcd. for $\mathrm{C}_{21} \mathrm{H}_{44} \mathrm{BrNO}_{2}$ : C, 59.70; H, 10.50; N, 3.32; found: C, 59.21; H, 10.98; N, 2.71 .

Bis(2-hydroxyethyl)methyloctadecylammonium bromide (3) ${ }^{1} \mathrm{H} \mathrm{NMR}\left(400 \mathrm{MHz}, \mathrm{CDCl}_{3}\right) \delta 0.88(\mathrm{t}, 3 \mathrm{H}, J 6.7 \mathrm{~Hz}$,
$\left.\mathrm{CH}_{3}\right), 1.26$ (s, 30H, $\left.\mathrm{CH}_{2}\right), 1.76\left(\mathrm{~d}, 2 \mathrm{H}, \mathrm{J} 5.5 \mathrm{~Hz}, \mathrm{CH}_{2}\right), 3.34$ (m, 3H, $\left.\mathrm{CH}_{3}\right), 3.56\left(\mathrm{~m}, 4 \mathrm{H}, \mathrm{CH}_{2}\right), 3.75\left(\mathrm{~m}, 4 \mathrm{H}, \mathrm{CH}_{2}\right), 4.10$ (s, $\left.4 \mathrm{H}, \mathrm{CH}_{2}\right), 4.80(\mathrm{~s}, 2 \mathrm{H}, \mathrm{OH}) ;{ }^{13} \mathrm{C} \mathrm{NMR}\left(100 \mathrm{MHz} \mathrm{CDCl}_{3}\right)$ $\delta$ 14.0, 22.5, 26.3, 29.2 (6), 29.4 (4), 29.5 (5), 31.7, 50.3, 55.6, 63.6, 63.9; anal. calcd. for $\mathrm{C}_{23} \mathrm{H}_{46} \mathrm{BrNO}_{2}$ : C, 61.59; H, 10.34; N, 3.12; found: C, 61.02; H, 10.92; N, 3.71.

Bis(2-hydroxyethyl)methyltetradecylammonium (4-chloro2-methylphenoxy)acetate (1a)

${ }^{1} \mathrm{H} \mathrm{NMR}\left(400 \mathrm{MHz}, \mathrm{CDCl}_{3}\right) \delta 0.88(\mathrm{t}, 3 \mathrm{H}, J 6.7 \mathrm{~Hz}$, $\left.\mathrm{CH}_{3}\right), 1.25$ (s, 22H, $\left.\mathrm{CH}_{2}\right), 1.55\left(\mathrm{~d}, 2 \mathrm{H}, J 5.5 \mathrm{~Hz}, \mathrm{CH}_{2}\right), 2.21$ (s, 3H, $\left.\mathrm{CH}_{3}\right), 3.03\left(\mathrm{~s}, 3 \mathrm{H}, \mathrm{CH}_{3}\right), 3.24\left(\mathrm{~m}, 2 \mathrm{H}, \mathrm{CH}_{2}\right), 3.42$ (m, $\left.4 \mathrm{H}, \mathrm{CH}_{2}\right), 3.91\left(\mathrm{~s}, 4 \mathrm{H}, \mathrm{CH}_{2}\right), 4.41(\mathrm{~s}, 2 \mathrm{H}, \mathrm{OH}), 5.27(\mathrm{~s}, 2 \mathrm{H}$, $\mathrm{CH}_{2}$ ), 6.65 (d, 1H, J 5.5 Hz, Ar-H), 7.05 (m, 2H, Ar-H); ${ }^{13} \mathrm{C} \mathrm{NMR}\left(100 \mathrm{MHz}, \mathrm{CDCl}_{3}\right) \delta 14.1,16.2,22.4,22.6,26.3$, $29.2(3), 29.3$ (2), 29.5 (2), $29.6(3), 31.8,49.8,55.5,63.6$, 63.9, 67.5, 112.5, 124.8, 126.2, 128.7, 130.2, 155.5, 174.1; anal. calcd. for $\mathrm{C}_{28} \mathrm{H}_{50} \mathrm{ClNO}_{5}$ : C, 65.16; H, 9.76; N, 2.71; found: C, 65.67; H, 9.22; N, 3.22.

Hexadecylbis(2-hydroxyethyl)methylammonium (4-chloro2-methylphenoxy)acetate (2a)

${ }^{1} \mathrm{H}$ NMR (400 MHz, CD $\left.3 \mathrm{OD}\right) \delta 0.89(\mathrm{t}, 3 \mathrm{H}, J 6.7 \mathrm{~Hz}$, $\left.\mathrm{CH}_{3}\right), 1.28\left(\mathrm{~s}, 26 \mathrm{H}, \mathrm{CH}_{2}\right), 1.76\left(\mathrm{~d}, 2 \mathrm{H}, \mathrm{J} 5.5 \mathrm{~Hz}, \mathrm{CH}_{2}\right), 2.25$ (s, 3H, $\mathrm{CH}_{3}$ ), 3.15 (s, 3H, $\left.\mathrm{CH}_{3}\right), 3.41\left(\mathrm{~m}, 4 \mathrm{H}, \mathrm{CH}_{2}\right), 3.52$ (s, $4 \mathrm{H}, \mathrm{CH}_{2}$ ), 3.96 (s, 4H, $\mathrm{CH}_{2}$ ), 4.39 (s, 2H, OH), 4.90 (s, 2H, $\mathrm{CH}_{2}$ ), 6.72 (d, 1H, J 5.5 Hz, Ar-H), 7.08 (m, 2H, Ar-H); ${ }^{13} \mathrm{C} \mathrm{NMR}\left(100 \mathrm{MHz}, \mathrm{CD}_{3} \mathrm{OD}\right) \delta 14.5,16.6,23.4,23.8,27.5$, 30.3 (2), 30.5 (4), 30.6 (3), 30.7 (2), 30.9, 33.1, 49.7, 56.7, 65.0, 65.1, 68.9, 113.5, 125.9, 127.2, 130.2, 131.2, 157.2, 176.4; anal. calcd. for $\mathrm{C}_{30} \mathrm{H}_{54} \mathrm{ClNO}_{5}$ : C, 66.21; H, 10.00; N, 2.57; found: C, 66.77; H, 9.49; N, 3.12.

Bis(2-hydroxyethyl)methyloctadecylammonium (4-chloro2-methylphenoxy)acetate (3a)

${ }^{1} \mathrm{H}$ NMR (400 MHz, CD 3 OD) $\delta 0.89(\mathrm{t}, 3 \mathrm{H}, J 6.7 \mathrm{~Hz}$, $\left.\mathrm{CH}_{3}\right), 1.28\left(\mathrm{~s}, 30 \mathrm{H}, \mathrm{CH}_{2}\right), 1.76\left(\mathrm{~d}, 2 \mathrm{H}, J 5.5 \mathrm{~Hz}, \mathrm{CH}_{2}\right)$, 2.25 (s, 3H, $\left.\mathrm{CH}_{3}\right), 3.14$ (s, 3H, $\left.\mathrm{CH}_{3}\right), 3.41\left(\mathrm{~m}, 4 \mathrm{H}, \mathrm{CH}_{2}\right)$, 3.52 (s, 4H, $\left.\mathrm{CH}_{2}\right), 3.95$ (s, 4H, $\left.\mathrm{CH}_{2}\right), 4.39$ (s, 2H, OH), $4,90\left(\mathrm{~s}, 2 \mathrm{H}, \mathrm{CH}_{2}\right), 6.72(\mathrm{~d}, 1 \mathrm{H}, J 5.5 \mathrm{~Hz}, \mathrm{Ar}-\mathrm{H}), 7.07$ (m, $2 \mathrm{H}, \mathrm{Ar}-\mathrm{H}) ;{ }^{13} \mathrm{C}$ NMR (100 MHz, $\left.\mathrm{CD}_{3} \mathrm{OD}\right) \delta$ 14.6, 16.6, 
$23.4,23.8,27.5,30.3$ (2), 30.5 (4), 30.6 (3), 30.7 (2), 30.8 (2), 30.9, 33.1, 50.3, 56.7, 65.0, 65.1, 68.9, 113.5, $125.9,127.2,130.2,131.2,157.2,176.4$; anal. calcd. for $\mathrm{C}_{32} \mathrm{H}_{58} \mathrm{ClNO}_{5}: \mathrm{C}, 67.16 ; \mathrm{H}, 10.22 ; \mathrm{N}, 2.45$; found: C, 67.67; H, 9.74; N, 2.00 .

Bis(2-hydroxyethyl)methyltetradecylammonium (2,4-dichlorophenoxy)acetic (1b)

${ }^{1} \mathrm{H}$ NMR (400 MHz, CD $\left.\mathrm{OD}\right) \delta 0.89$ (t, $3 \mathrm{H}, J 6.7 \mathrm{~Hz}$, $\left.\mathrm{CH}_{3}\right), 1.28\left(\mathrm{~s}, 22 \mathrm{H}, \mathrm{CH}_{2}\right), 1.78\left(\mathrm{~d}, 2 \mathrm{H}, J 5.5 \mathrm{~Hz}, \mathrm{CH}_{2}\right), 3.18$ (s, $\left.3 \mathrm{H}, \mathrm{CH}_{3}\right), 3.44\left(\mathrm{~m}, 2 \mathrm{H}, \mathrm{CH}_{2}\right), 3.55\left(\mathrm{~m}, 4 \mathrm{H}, \mathrm{CH}_{2}\right), 3.98$ (s, $\left.4 \mathrm{H}, \mathrm{CH}_{2}\right), 4.48$ (s, 2H, OH), $4.88\left(\mathrm{~s}, 2 \mathrm{H}, \mathrm{CH}_{2}\right), 6.9(\mathrm{~d}, 1 \mathrm{H}$, $J 5.5 \mathrm{~Hz}, \mathrm{Ar}-\mathrm{H}), 7.21(\mathrm{~m}, 1 \mathrm{H}, \mathrm{Ar}-\mathrm{H}), 7.36(\mathrm{~d}, 1 \mathrm{H}, J 5.7 \mathrm{~Hz}$, $\mathrm{Ar}-\mathrm{H}) ;{ }^{13} \mathrm{C}$ NMR $\left(100 \mathrm{MHz}, \mathrm{CD}_{3} \mathrm{OD}\right) \delta 14.6,23.4,23.7$, 27.4, 30.5 (3), 30.6 (2), 30.7 (3), 30.8 (2), 33.1, 50.4, 56.7, 65.0, 65.1, 69.4, 115.9, 124.5, 126.4, 128.6, 130.6, 154.9, 175.1; anal. calcd. for $\mathrm{C}_{27} \mathrm{H}_{47} \mathrm{Cl}_{2} \mathrm{NO}_{5}$ : C, 60.44; $\mathrm{H}, 8.83$; $\mathrm{N}, 2.61$; found: C, 59.92; H, 9.34; N, 2.08 .

Hexadecylbis(2-hydroxyethyl)methylammonium (2,4-dichlorophenoxy)acetic (2b)

${ }^{1} \mathrm{H}$ NMR (400 MHz, CD 3 OD) $\delta 0.89(\mathrm{t}, 3 \mathrm{H}, J 6.7 \mathrm{~Hz}$, $\left.\mathrm{CH}_{3}\right), 1.28\left(\mathrm{~s}, 26 \mathrm{H}, \mathrm{CH}_{2}\right), 1.78\left(\mathrm{~d}, 2 \mathrm{H}, J 5.5 \mathrm{~Hz}, \mathrm{CH}_{2}\right), 3.18$ (s, $\left.3 \mathrm{H}, \mathrm{CH}_{3}\right), 3.44\left(\mathrm{~m}, 2 \mathrm{H}, \mathrm{CH}_{2}\right), 3.55\left(\mathrm{~m}, 4 \mathrm{H}, \mathrm{CH}_{2}\right), 3.98$ (s, $\left.4 \mathrm{H}, \mathrm{CH}_{2}\right), 4.48(\mathrm{~s}, 2 \mathrm{H}, \mathrm{OH}), 4.88\left(\mathrm{~s}, 2 \mathrm{H}, \mathrm{CH}_{2}\right), 6.9(\mathrm{~d}, 1 \mathrm{H}$, $J 5.8 \mathrm{~Hz}, \mathrm{Ar}-\mathrm{H}), 7.21(\mathrm{~m}, 1 \mathrm{H}, \mathrm{Ar}-\mathrm{H}), 7.36(\mathrm{~d}, 1 \mathrm{H}, J 5.7 \mathrm{~Hz}$, $\mathrm{Ar}-\mathrm{H}) ;{ }^{13} \mathrm{C}$ NMR (100 MHz, $\left.\mathrm{CD}_{3} \mathrm{OD}\right) \delta 14.6,23.5,23.8$, 27.5, 30.4 (2), 30.5 (4), 30.6 (3), 30.7 (3), 33.1, 50.4, 56.7, 65.0, 65.1, 69.4, 115.8, 124.6, 126.4, 128.6, 130.6, 154.9, 175.2; anal. calcd. for $\mathrm{C}_{29} \mathrm{H}_{51} \mathrm{Cl}_{2} \mathrm{NO}_{5}$ : C, 61.69; $\mathrm{H}, 9.10$; $\mathrm{N}, 2.48$, found: C, 61.18; H, 9.61; N, 2.99 .

\section{Bis(2-hydroxyethyl)methyloctadecylammonium (2,4-dichlorophenoxy)acetic (3b)}

${ }^{1} \mathrm{H}$ NMR (400 MHz, $\left.\mathrm{CD}_{3} \mathrm{OD}\right) \delta 0.89(\mathrm{t}, 3 \mathrm{H}, J 6.7 \mathrm{~Hz}$, $\left.\mathrm{CH}_{3}\right), 1.28\left(\mathrm{~s}, 30 \mathrm{H}, \mathrm{CH}_{2}\right), 1.78\left(\mathrm{~d}, 2 \mathrm{H}, J 5.5 \mathrm{~Hz}, \mathrm{CH}_{2}\right)$, $3.18\left(\mathrm{~s}, 3 \mathrm{H}, \mathrm{CH}_{3}\right), 3.44\left(\mathrm{~m}, 2 \mathrm{H}, \mathrm{CH}_{2}\right), 3.55\left(\mathrm{~m}, 4 \mathrm{H}, \mathrm{CH}_{2}\right)$, 3.98 (s, $\left.4 \mathrm{H}, \mathrm{CH}_{2}\right), 4.48$ (s, $\left.2 \mathrm{H}, \mathrm{OH}\right), 4.88\left(\mathrm{~s}, 2 \mathrm{H}, \mathrm{CH}_{3}\right)$, $6.91(\mathrm{~d}, 1 \mathrm{H}, J 9.8 \mathrm{~Hz}, \mathrm{Ar}-\mathrm{H}), 7.21(\mathrm{~m}, 1 \mathrm{H}, \mathrm{Ar}-\mathrm{H}), 7.36$ (d, $1 \mathrm{H}, J 9.7 \mathrm{~Hz}, \mathrm{Ar}-\mathrm{H}) ;{ }^{13} \mathrm{C}$ NMR $\left(100 \mathrm{MHz}, \mathrm{CD}_{3} \mathrm{OD}\right)$ $\delta$ 14.6, 23.5, 23.8, 27.5, 30.3 (2), 30.4 (2), 30.5 (4), 30.6 (3), 30.7 (3), 33.1, 50.4, 56.8, 65.0, 65.1, 69.3, 115.9, 124.6, 126.5, 128.6, 130.7, 154.9, 175.1; anal. calcd. for $\mathrm{C}_{31} \mathrm{H}_{55} \mathrm{Cl}_{2} \mathrm{NO}_{5}: \mathrm{C}, 62.82 ; \mathrm{H}, 9.35 ; \mathrm{N}, 2.36$; found: C, 63.38; $\mathrm{H}, 9.81 ; \mathrm{N}, 2.89$.

\section{Thermal analysis}

Thermal transitions of the prepared salts were determined by differential scanning calorimetry (DSC), with a Mettler Toledo Star TGA/DSC1 unit, under nitrogen. Samples between 5 and $15 \mathrm{mg}$ were placed in aluminum pans and heated from 25 to $120^{\circ} \mathrm{C}$ at a heating rate of $10{ }^{\circ} \mathrm{C} \mathrm{min}^{-1}$, and cooled with an intracooler at a cooling rate of $10{ }^{\circ} \mathrm{C} \mathrm{min}^{-1}$ to $-100^{\circ} \mathrm{C}$. Thermogravimetric analysis (TGA) was performed using a Mettler Toledo Star TGA/DSC1 unit, under nitrogen. Samples between 2 and $10 \mathrm{mg}$ were placed in aluminum pans and heated from 30 to $450{ }^{\circ} \mathrm{C}$ at a heating rate of $10{ }^{\circ} \mathrm{C} \mathrm{min}$.

\section{Surface tension}

The surface tension was determined using the drop shape method. The surface tension $\left(\gamma\right.$ in $\left.\mathrm{mN} \mathrm{m}^{-1}\right)$ is calculated by analyzing the profile of the drop according to the Laplace equation.

Surface tension measurements were carried out by the use of a drop shape analyzer (DSA) (Krüss DSA 100 , accuracy $\pm 0.01 \mathrm{mN} \mathrm{m}^{-1}$ ), at $25{ }^{\circ} \mathrm{C}$. Temperature was controlled using a Fisherbrand FBH604 thermostatic bath (Fisher, accuracy $\pm 0.1^{\circ} \mathrm{C}$ ). The values of the critical micelle concentration $(\mathrm{CMC})$ and the surface tension at the CMC ( $\gamma \mathrm{CMC})$ were determined from the intersection of the two straight lines drawn in low and high concentration regions in surface tension curves ( $\gamma$-log $\mathrm{C}$ curves) using a linear regression analysis method.

\section{Wettability}

Surface active agents tend to prevent drops from running off the leaf and improve wettability of a herbicide formulation. The basis for the wettability is the drop shape analysis and contact angle measurements. Values of contact angle were determined from the image of the drop. After determination of actual drop shape and the contact line, the drop shape is adapted to fit a mathematical model used to calculate the contact angle. The most exact method to calculate this value is Young-Laplace fitting (sessile drop fitting), where complete drop contour is evaluated. After successful fitting of the Young-Laplace equation, the contact angle was determined as the slope of the contour line at the 3-phase contact point (solid-liquid, liquid-air and air-solid). The solid phase was paraffin. This surface is a common wrap material used for a variety of purposes in laboratories, and is often used as a standard model for a waxy leaf surface, due to its high contact angle with water of $120^{\circ}$. The contact angle for water on waxy leaf surfaces varies by type from 90 to $150^{\circ}$ in extreme cases, but in general, the value of $120^{\circ}$ is a median, making paraffin very suitable as a model. The measurements were carried out by the use of DSA 100 analyzer described earlier (Figure 1). 

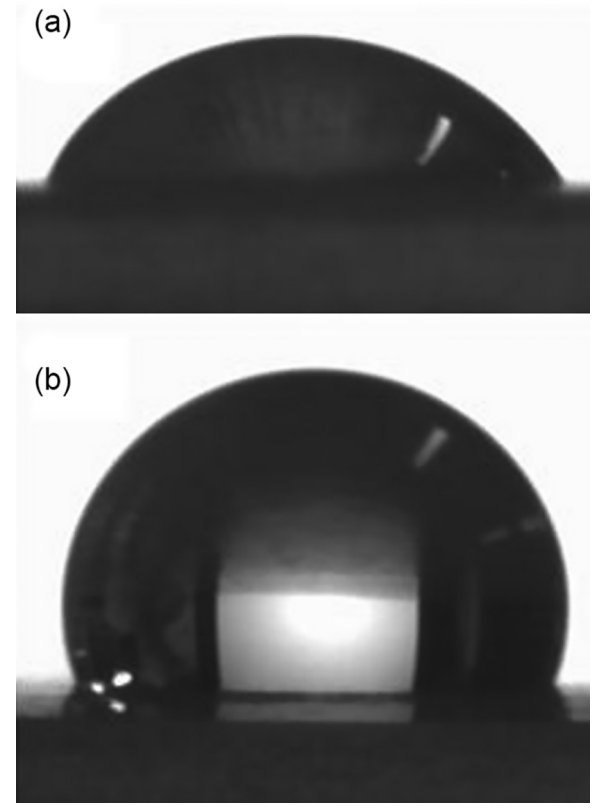

Figure 1. Drop of (a) the studied IL 1a and (b) water.

\section{Biological activity}

The herbicidal efficacy of the obtained HILs was tested using common lambsquarters (Chenopodium album L.) and white mustard (Sinapis alba L.) as the test plants. All HILs were dissolved in a mixture of water and ethanol $(1: 1 \mathrm{v} / \mathrm{v})$. Commercial products Chwastox Extra $300 \mathrm{SL}$ (300 g of sodium and potassium salts of MCPA in $1 \mathrm{~L}$ ) and Aminopielik Standard $600 \mathrm{SL}$ (600 g of dimethylammonium salts of 2,4-D in $1 \mathrm{~L}$ ) dissolved in water and ethanol $(1: 1 \mathrm{v} / \mathrm{v})$ were used as reference treatments. All herbicides were used at the sub-lethal dose of $400 \mathrm{~g}$ active ingredient per 1 ha, for better evaluation of the differences in the effectiveness of their action on weeds.

Plant seeds were sown into plastic pots $(0.5 \mathrm{~L})$ and kept in a greenhouse at a temperature of $20^{\circ} \mathrm{C}$, humidity of $60 \%$ and photoperiod of $16 / 8 \mathrm{~h}$ day/night. The plants were thinned to five per pot 10 days after emergence, and watered as needed. The plants were treated by herbicides at 4-6 leaf growth stage. The treatments were applied using a moving sprayer (APORO) with TeeJet 110/02 flat-fan nozzles (TeeJet Technologies) delivering $200 \mathrm{~L}$ of spray solution per 1 ha at $0.2 \mathrm{MPa}$ operating pressure. The distance from the nozzles to the tips of the plant was $40 \mathrm{~cm}$. Efficacy was evaluated using the fresh weight reduction method (at $0.01 \mathrm{~g}$ accuracy) two weeks after treatment (2 WAT). Data were expressed as percent of fresh weight reduction compared with untreated plants. The reduction of plant fresh weight was measured and compared to control plants, which were not sprayed with herbicide.
Statistical analysis

All the experiments were conducted in triplicate and all error bars presented on Figures represent standard errors of the mean (with respect to the number of replicates).

\section{Results and Discussion}

Prepared quaternary ammonium salts

The first experimental step was focused on the preparation of alkylbis(2-hydroxyethyl)ammonium bromides by conducting the Menschutkin reaction using bis(2-hydroxyethyl)methylamine and an appropriate quaternizing agent, which was 1-bromotetradecane in case of salt 1, 1-bromohexadecane (2) and 1-bromooctadecane (3). Quaternary ammonium bromides were solids with a purity higher than $96 \%$ (surfactant content).

Afterwards, 6 new salts were obtained in neutralization reaction using a quaternary bromide as the source of cation and different herbicidal acids, such as MCPA and 2,4-D. The acid-base reaction occurred immediately at room temperature $\left(25^{\circ} \mathrm{C}\right)$ and allowed to obtain compounds with yields between 90 and $95 \%$ (Table 1), which correspond well with the yield of other alkylammonium herbicidal ionic liquids..$^{10}$ The prepared salts were characterized by ${ }^{1} \mathrm{H}$ and ${ }^{13} \mathrm{C}$ NMR and elemental analysis. The ${ }^{1} \mathrm{H}$ NMR spectra of synthesized salts indicated the presence of hydroxyl groups (3.65 ppm). A characteristic signal from protons of alkyl chain occurred in the range from 1.19 to $1.32 \mathrm{ppm}$. Every compound presented more impurity than shown in Table 2, since prepared salts were hygroscopic and easily absorbed water from air. It can influence on the elemental analysis results. Subsequent studies focused on investigation of the solubility of the obtained compounds. All of the obtained salts exhibited a melting temperature below $100{ }^{\circ} \mathrm{C}$, therefore they may be classified as ionic liquids.

\section{Solubility analysis}

The obtained ILs were stable in air and in contact with water or common organic solvents. The solubility of the obtained salts in selected solvents (such as water, dimethylsulfoxide (DMSO), acetonitrile, acetone, 2-isopropanol, ethyl acetate, chloroform, toluene and hexane) was determined according to Vogel and Furniss. ${ }^{24}$ All of the synthesized salts were soluble in methanol, chloroform and poorly in DMF. With one exception (1a), the synthesized salts were soluble in DMSO. Salts 1-3 and $\mathbf{1 b}-\mathbf{3 b}$ were soluble in 2-isopropanol. Limited solubility in water was observed when using $2,4-\mathrm{D}$ as an anion. 
None of the prepared salts were soluble in acetonitrile. Thermal stability of the obtained ILs was studied in next experimental step.

\section{Thermal analysis}

Thermal analysis (DSC and TGA) of selected ionic liquids $(\mathbf{1 a}, \mathbf{2 a}, \mathbf{1 b}$, and $\mathbf{2 b})$ is presented in Table 3. Analysis of phase transitions in the examined temperature range indicates glass transition temperature, temperature of crystallization and melting point for analyzed ILs. They were thermally stable between 225 and $230^{\circ} \mathrm{C}$ and showed glass transition temperature in the range of -37 to $-5^{\circ} \mathrm{C}$. Thermal stability values are in accordance with the $\mathrm{T}_{\text {onset }}$ value obtained for [Ethoquad C/12][2,4-D], which was equal to $222{ }^{\circ} \mathrm{C} .{ }^{10}$ For all samples the melting point was below $100{ }^{\circ} \mathrm{C}$ and $\mathbf{1 b}$ reached a value of melting point approximately equal to room temperature $\left(24{ }^{\circ} \mathrm{C}\right)$. After analysis of thermal stability the obtained ILs were subjected to investigation of surface activity.

Table 3. Thermal analysis (DSC and TGA) of the synthesized Ils

\begin{tabular}{|c|c|c|c|c|c|}
\hline ILs & $\mathrm{Tg}^{\mathrm{a}} /{ }^{\circ} \mathrm{C}$ & $\mathrm{Tc}^{\mathrm{b}} /{ }^{\circ} \mathrm{C}$ & $\mathrm{Tm}^{\mathrm{c}} /{ }^{\circ} \mathrm{C}$ & $\mathrm{T}_{\text {onset } 5 \%}{ }^{\mathrm{d}} /{ }^{\circ} \mathrm{C}$ & $\mathrm{T}_{\text {onset }}{ }^{\mathrm{e}} /{ }^{\circ} \mathrm{C}$ \\
\hline $1 \mathrm{a}$ & -37 & -6 & 36 & 225 & 332 \\
\hline $2 a$ & -28 & 0 & 40 & 230 & 350 \\
\hline $1 b$ & -36 & -1 & 24 & 225 & 272 \\
\hline $2 b$ & -5 & 6 & 40 & 228 & 282 \\
\hline
\end{tabular}

${ }^{\mathrm{a}} \mathrm{Tg}$ : glass transition temperature; ${ }^{\mathrm{b}} \mathrm{Tc}$ : temperature of crystallization; 'Tm: melting point; ${ }^{\mathrm{d}} \mathrm{T}_{\text {onset } 5 \%}$ : decomposition temperature of $5 \%$ of sample; ${ }^{\mathrm{e}} \mathrm{T}_{\text {onset }}:$ decomposition temperature of $50 \%$ of sample. ILs: ionic liquids.

\section{Surface activity}

Table 4 presents parameters of surface activity: $\mathrm{CMC}$, surface tension at $\mathrm{CMC}$ and contact angle (CA). It is observed that the length of the alkyl chain was, as expected, decisive for the CMC of aqueous solutions of obtained ILs. The elongation of alkyl chain length caused a decrease from 0.45 to $0.06 \mathrm{mmol} \mathrm{dm}^{-3}$ for $\mathbf{1 a - 3 a}$ (MCPA anion), and 0.5 to $0.06 \mathrm{mmol} \mathrm{dm}^{-3}$ for $\mathbf{1 b}-\mathbf{3 b}$ (2,4-D anion). This is due to enhanced hydrophobic interaction between the counter ion and micelle. These CMC values are comparable with typical ionic surface active agents. Surface activity of the synthesized ILs can also be evaluated by the surface tension $(\gamma \mathrm{CMC})$. Surface tension of aqueous solutions of studied ILs decreased from water value to a minimum located from 34 to $38.5 \mathrm{mN} \mathrm{m}^{-1}$, where it reached a plateau. In the group of compounds 1a-3a with MCPA anion, the surface tension was reduced to a minimum for $\mathbf{2 a}$, reaching $34.0 \mathrm{mN} \mathrm{m}^{-1}$.
In the homologous series of compounds $\mathbf{1 b} \mathbf{b} \mathbf{3 b}$ comprising the 2,4-D anion, the surface tension was reduced to $34.4 \mathrm{mN} \mathrm{m}^{-1}$. After comparing the designated CMC and $\gamma \mathrm{CMC}$ values for obtained ILs with two different anions (MCPA and 2,4-D) no significant differences between these two groups were observed. Both demonstrated high surface activity and lowered the surface tension of water to a similar range. In comparison, the surface tension for [Ethoquad C/12][2,4-D], which is a mixture of cations with defined long alkyl substituent, ranged from 30.4 to $32.5 \mathrm{mN} \mathrm{m}^{-1}$. $^{10,25}$

Table 4. Surface activity parameters of synthesized Ils

\begin{tabular}{cccc}
\hline $\mathrm{ILs}$ & $\mathrm{CMC}^{\mathrm{a}} /\left(\mathrm{mmol} \mathrm{dm}^{-1}\right)$ & $\gamma^{\mathrm{b}} /\left(\mathrm{mN} \mathrm{m}^{-1}\right)$ & $\mathrm{CA}^{\mathrm{c}} /$ degree \\
\hline $\mathbf{1 a}$ & 0.45 & 35.1 & 65.8 \\
$\mathbf{2 a}$ & 0.16 & 34.0 & 64.3 \\
3a & 0.06 & 38.5 & 70.7 \\
$\mathbf{1 b}$ & 0.50 & 34.4 & 64.1 \\
2b & 0.13 & 35.2 & 68.6 \\
$\mathbf{3 b}$ & 0.06 & 37.2 & 71.6 \\
\hline
\end{tabular}

${ }^{\mathrm{a}} \mathrm{CMC}$ : critical micelle concentration; ${ }^{\mathrm{b}} \gamma$ : surface tension at $\mathrm{CMC}$; ${ }^{\mathrm{C}} \mathrm{CA}$ : contact angle. ILs: ionic liquids.

The aqueous solutions of the studied ILs reduced contact angle of water from approximately 120 to 64.3-70.7 ${ }^{\circ}$ for 4-chloro-2-methylphenoxyacetates, and 64.1-71. $6^{\circ}$ for 2,4-dichlorophenoxyacetates (Table 4). According to literature reports, the contact angle value for [Ethoquad C/12][2,4-D] ranged from 51.80 to $54.32^{\circ} .{ }^{10,25}$ Paraffin, which is strongly hydrophobic, was the solid phase. The lowest contact angles on the hydrophobic surface were exhibited by the liquids with the lowest surface tensions. Good wettability of a solid material (paraffin), which imitates the real surface of leaves, is useful for employing the new compounds as herbicides in future applications.

\section{Herbicidal activity}

The greenhouse experiments were carried out in order to establish the biological activity of the synthesized ILs. The activity of HILs 1a-3b was tested against common lambsquarters and white mustard. The efficacy of the tested herbicides was at a low level (18-60\%), which resulted from the application of sub-lethal doses. The data presented in Figure 2 indicate that the synthesized ILs have herbicidal activity and may be classified as HILs.

Results show that the chain length ranging from 14 to 18 carbon atoms in alkylbis(2-hydroxyethyl)ammonium cation does not have a significant relevance to the herbicidal 
(a)

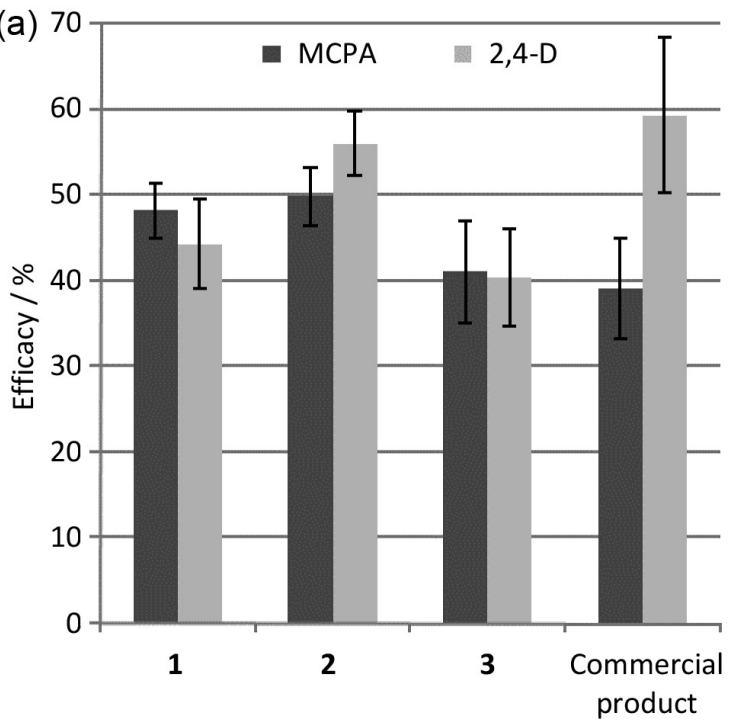

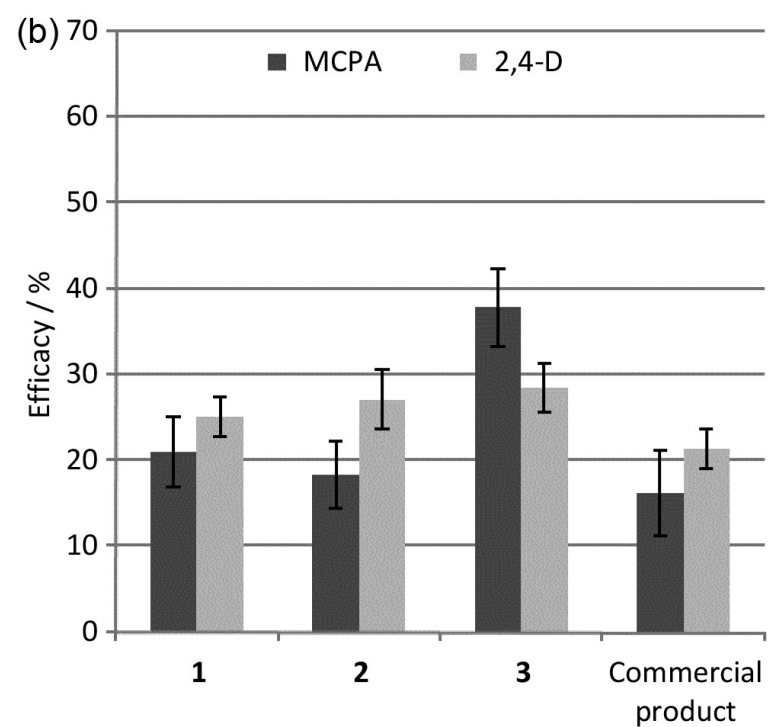

Figure 2. Fresh weight reduction as influenced by tested HILs and commercial products for (a) common lambsquarters, (b) white mustard.

activity of tested ILs towards weeds. The biological activity of HILs depended mainly on plant species. For example HIL 3a, which contained bis(2-hydroxyethyl) methyloctadecylammonium (4-chloro-2-methylphenoxy) acetate, was the most effective treatment against common lambsquarters, but it was less active against white mustard plants compared with other tested compounds. Among the HILs containing the 2,4-D anion, the most effecive treatment was observed for the compound with hexadecylbis(2hydroxyethyl)methylammonium cation used against white mustard, but its efficacy against common lamsquarters was similar to other tested compounds (Figure 3).
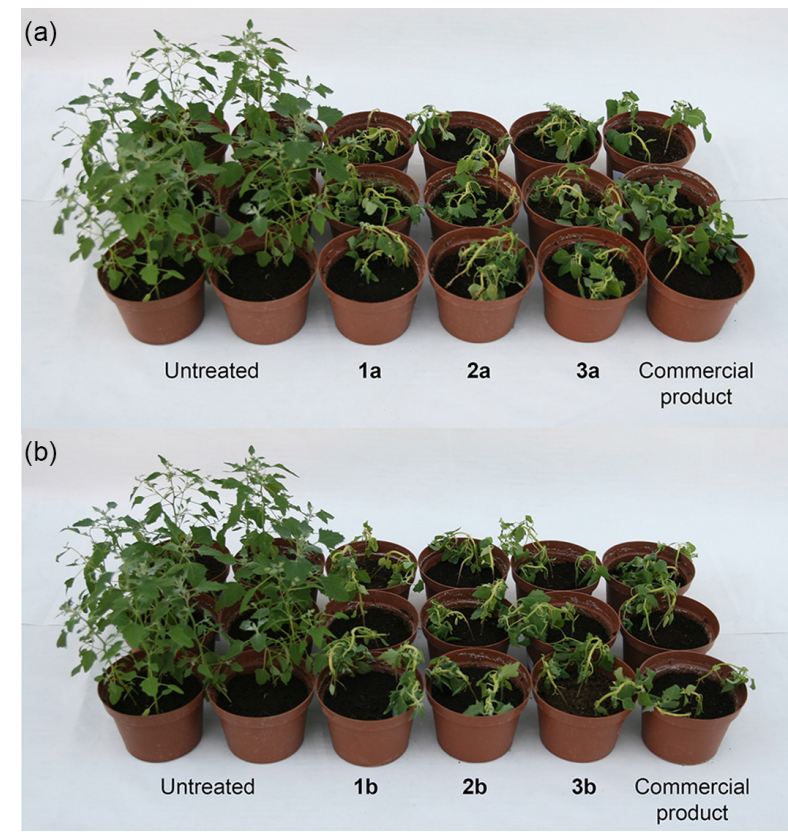

Figure 3. Control of common lambsquarters by tested treatments: (a) MCPA, and (b) 2,4-D.

\section{Conclusions}

Commonly used herbicides can be modified by the addition of a long chain ammonium cation. The acid-base reaction occurred immediately at room temperature and allowed to obtain compounds with yields between 90 and $95 \%$. All the obtained salts exhibited melting points below $100{ }^{\circ} \mathrm{C}$. New forms of MCPA and 2,4-D as HILs were stable in air as well as in contact with water and organic solvents. Length of the alkyl substituent in cation affected the surface activity, thermal stability and solubility. All HILs were thermally stable below $225^{\circ} \mathrm{C}$. Surface activity depended on the length of substituent and on the type of herbicidal anion. The surface tension was reduced to a minimum for HILs 2a and $\mathbf{1 b}$, which confirms the influence of the anion on surface activity of HILs. Good wettability of a solid material (paraffin), which imitates the surface of leaves, may be useful for employing the new compounds as herbicides in future applications. The highest efficacy of fresh weight reduction in the comparison to the commercial formulation was observed for HILs 2a against common lambsquaters and $\mathbf{3 b}$ against white mustard. Their herbicidal activity has been preserved and it was observed that the chain length of carbon atoms in alkylbis(2-hydroxyethyl)ammonium cation had a relevant influence on the performance of the tested ILs towards weeds.

In most cases, new forms of MCPA and 2,4-D showed similar effectiveness as reference products. However, other advantages such as low volatility are important from the point of view of operator's safety aerial drift of herbicide molecules to the not-target plants. Therefore, HILs may be an interesting alternative to commercial pesticides. HILs are a group of ionic liquids, which is still developing 
and may be an alternative to the cultivation of genetically modified plants.

\section{Supplementary Information}

Supplementary information is available free of charge at http://jbcs.sbq.org.br as PDF file.

\section{Acknowledgments}

This work supported by grant No. PBS2/A1/9/2013.

\section{References}

1. Wasserscheid, P.; Welton, T.; Ionic Liquids in Synthesis, $2^{\text {nd }}$ ed.; Wiley-VCH: Weinheim, 2007.

2. Petkovic, M.; Seddon, K. R.; Rebelo L. P. N.; Chem. Soc. Rev. 2011, 40, 1383.

3. Welton, T.; Chem. Rev. 1999, 99, 2071.

4. Gordon, C. M.; Appl. Catal., A 2001, 222, 101.

5. Lagrost, C.; Carrié, D.; Vaultier, M.; Hapiot, P.; J. Phys. Chem. A 2003, 107, 745.

6. Bica, K.; Rodriguez, H.; Gurau, G.; Cojocaru, O. A.; Riisager, A.; Fehrmann, R.; Rogers, R. D.; Chem. Commun. 2012, 48, 5422.

7. Pernak, J.; Nawrot, J.; Kot, M.; Markiewicz, B.; Niemczak, M.; RSC Adv. 2013, 3, 25019.

8. Markiewicz, B.; Sznajdrowska, A.; Chrzanowski, Ł.; Ławniczak, Ł.; Zgoła-Grześkowiak, A.; Kubiak, K.; Nawrot, J.; Pernak, J.; New J. Chem. 2014, 38, 3146.

9. Pernak, J.; Markiewicz, B.; Łęgosz, B.; Walkiewicz, F.; Gwiazdowski, R.; Praczyk, T.; RSC Adv. 2015, 5, 9695.

10. Pernak, J.; Syguda, A.; Janiszewska, D.; Materna, K.; Praczyk, T.; Tetrahedron 2011, 26, 4838.

11. Tomlin, C. D. S.; The Pesticide Manual, A World Compendium, $15^{\text {th }}$ ed.; British Crop Protection Council: Alton, 2009.
12. Grossmann, K. In Herbicides and Their Mechanisms of Action; Cobb, A. H.; Kirkwood, R. C., eds.; Sheffield Academic Press: Sheffield, 2000, p. 181.

13. Pernak, J.; Niemczak, M.; Materna, K.; Marcinkowska, K.; Praczyk, T.; Tetrahedron 2013, 69, 4665.

14. Pernak, J.; Syguda, A.; Materna, K.; Janus, E.; Kardasz, P.; Praczyk, T.; Tetrahedron 2012, 68, 4267.

15. Praczyk, T.; Kardasz, P.; Jakubiak, E.; Syguda, A.; Materna, K.; Pernak, J.; Weed Sci. 2012, 60, 189.

16. Cojocaru, O. A.; Shamshina, J. L.; Gurau, G.; Syguda, A.; Praczyk, T.; Pernak, J.; Rogers, R. D.; Green Chem. 2013, 15, 2110.

17. Pernak, J.; Czerniak, K.; Niemczak, M.; Chrzanowski, Ł.; Ławniczak, Ł.; Fochtman, P.; Marcinkowska, K.; Praczyk, T.; New J. Chem. 2015, 39, 5715.

18. Ding, G.; Liu, Y.; Wang, B.; Punyapitak, D.; Guo, M.; Duan, Y.; Li, J.; Cao, Y.; New J. Chem. 2014, 38, 5590.

19. Pernak, J.; Niemczak, M.; Zakrocka, K.; Praczyk, T.; Tetrahedron 2013, 69, 8132.

20. Kordala-Markiewicz, R.; Rodak, H.; Markiewicz, B.; Walkiewicz, F.; Sznajdrowska, A.; Materna, K.; Marcinkowska, K.; Praczyk, T.; Pernak, J.; Tetrahedron 2014, 70, 4784.

21. Pernak, J.; Niemczak, M.; Giszter, R.; Shamshina, J. L.; Gurau, G.; Cojocaru, O. A.; Praczyk, T.; Marcinkowska, K.; Rogers, R. D.; ACS Sustainable Chem. Eng. 2014, 2, 2845.

22. Pernak, J.; Niemczak, M.; Shamshina, J. L.; Gurau, G.; Głowacki, G.; Praczyk, T.; Marcinkowska, K.; Rogers, R. D.; J. Agric. Food. Chem. 2015, 63, 3357.

23. Niemczak, M.; Giszter, R.; Czerniak, K.; Marcinkowska, K.; Walkiewicz, F.; RSC Adv. 2015, 5, 15487.

24. Vogel, A. I.; Furniss, B. S.; Textbook of Practical Organic Chemistry; WNT: Warsaw, 2006.

25. Praczyk, T.; Kardasz, P.; Jakubiak, E.; Syguda, A.; Materna, K.; Pernak, J.; Weed Sci. 2012, 60,189.

Submitted: December 18, 2015 Published online: February 18, 2016 